\title{
METHODS OF RESTRICTION OF WATER INFLOWS IN GAS AND GAS CONDENSATE WELLS
}

\section{• . ник ровский, • • ник ровский}

V. V. Panikarovski, E. V. Panikarovski

юменский госуд рственный нефтег зовый университет, г. юмень

лючевые слов : н сосно-компрессорные трубы; водоизоляция; пл стовое д вление; приз бойн я зон пл $\mathrm{cm}$

Key words: oil-well tubing, water isolation; reservoir pressure; bottomhole formation zone

пыт р зр ботки г зовых месторождений в условиях ном льно низких пл стовых д влений ( ) пок зыв ет, что основные осложнения при эксплу т ции скв жин с обр зов нием гидр тных пробок возник ют в н сосно-компрессорных труб х ( ) и устьевом оборудов нии, т кже связ ны с возникновением межколонных г зопроявлений, появлением жидкости и песк н поздних ст диях эксплу т ции. ля предотвр щения обр зов ния гидр тов скв жины обр б тыв ют р створ ми диэтиленгликоля, мет нол , хлористого к льция.

ля предотвр щения межколонных перетоков г 3 из сеном нских и туронсенонских з лежей в конструкции эксплу т ционных скв жин предусмотрен удлиненный кондуктор, н д турон-сенонскими отложениями предусмотрен уст новк 3 колонного п кер 15-205.

ля предотвр щения обводнения скв жин и бр зивного износ оборудов ния, свя3 нного с появлением в продукции скв жин песк и воды, необходимо проведение 
профил ктических мероприятий по уд лению скопившейся н з бое скв жин конденс ционной и пл стовой воды, т кже проведение ремонтных р бот по изоляции водоприток и з креплению приз бойной зоны ( ).

ри уд лении жидкости с $з$ боя г зовой скв жины рекомендуется использов ть p зличные поверхностно- ктивные веществ ( ). к честве необходимо использов ть сульф нол, - , неонол для минер лизов нных вод, для сл боминер лизов нных вод с минер лиз цией меньше 10 г/л - другие виды : -7 , -10 .

случ е изоляции пл стовых вод предл г ются р зличные селективные изоляционные м тери лы: композиции из цетон , стиром ли и кремнийорг нические жидкости: $\quad-$ или водоизолирующие сост вы: $\quad-1, \quad-2$ и др.

ибольшую эффективность при проведении водоизоляционных р бот получили технологии, основ нные н 3 к чив нии в скв жину селективной водоизоляционной композиции н основе модифик тор с кремнийорг нической жидкостью с уст новкой водоизоляционного экр н [1].

ля предотвр щения вынос песк и з крепления скелет горных пород в конструкциях г зовых скв жин предусмотрено использов ние противопесочных фильтров, уст н влив емых н лифтовой колонне, и з крепляющих м тери лов: форм льдегидных смол, п р форм льдегид, древесной муки и н полнителя - бик рбон т н трия.

боты по водоизоляции н ынг пуровском и омсомольском месторождениях выполнялись 3 к чив нием гелеобр зующей композиции н основе жидкого стекл с отвердителем лимонной кислотой с последующим прод влив нием композиции в обводненную ч сть продуктивного пл ст и з креплением с помощью цементного мост .

скв жин х мсовейского и едвежьего месторождений для проведения водоизоляционных $\mathrm{p}$ бот в продуктивные пл сты 3 к чив ют водоизоляционный сост в н основе ре гент « 》с последующим 3 креплением его цементным р створом. ысокую эффективность н этих месторождениях при проведении изоляционных $\mathrm{p}$ бот будут иметь сост вы и композиции н основе силик тного ре гент « », применение которых имеет ряд преимуществ при проведении водоизоляционных р бот в условиях отриц тельных темпер тур.

ехнология изоляции подошвенных вод в г зовых скв жин х с включ ет уст новку водоизоляционного экр н н основе ре гент « » 3 креплением его цементным мостом. ыполненные р боты по д нной технологии позволяют з купорив ть основные водопроводящие к н лы гелеобр зующим сост вом н основе ре гент

« $\quad$ ", крупные трещины 3 полняются цементным р створом. сновным недост тком д нной технологии является снижение фильтр ционной х $\mathrm{p}$ ктеристики

ля укрепления скв жин предл г ется использов ть портл ндцемент с доб влением полипропиленовой фибры и суперпл стифик тор, что позволяет увеличить толщину цементного кольц 3 эксплу т ционной колонной при н личии пл стовой жидкости в скв жине.

спешное проведение водоизоляционных р бот и крепления может обеспечить созд ние 3 колонного фильтр из вулк низиров нной резины. сновной ч стью предл г емой технологии является з к чк и прод влив ние по в водного p створ к рбоксиметилцеллюлозы ( $)$ с измельченной сырой резиной и р счетным количеством люминия. о з трубному простр нству прод влив ют в $20 \%$-ный р створ соляной кислоты, который вз имодействует с люминием. результ те термохимической ре кции между люминием и соляной кислотой выделяется тепло, которое способствует вулк низ ции резины и сцеплению ее с поверхностью породы-коллектор , выделяющийся при этом водород созд ет дополнительные к н лы в общей м ссе резины, прониц емые для г 3 , что обеспечив ет крепление и сниж ет вынос песк [2].

езульт ты л бор торных исследов ний, проведенных н сл босцементиров нных обр зц х керн , ук зыв ют н получение прониц емого фильтр , который обеспечив ет устойчивость и предотвр щ ет вынос песк в ствол скв жины (т бл. 1).

ля проведения водоизоляционных $\mathrm{p}$ бот $\mathrm{p}$ зр бот н сост в, который обеспечив ет к чественную изоляцию пл стовых вод и з крепление обводнившихся скв жин, 
приз бойн я зон которых предст влен сл босцементиров нными коллектор ми с высокой прониц емостью.

езульт ты экспериментов по определению прониц емости обр зцов, устойчивых квыносу песк

\begin{tabular}{|c|c|c|c|c|c|c|}
\hline $\begin{array}{c}\text { № } \\
\text { опыт }\end{array}$ & $\begin{array}{c}\text { ост в } \\
\text { створ } \\
\text { ст чки } \\
\text { кислоты, }\end{array}$ & епрессия, & $\begin{array}{c}\text { рониц емость } \\
\text { сл босцемен- } \\
\text { тиров нных } \\
\text { обр зцов, } \\
10^{-3} \text { мкм }\end{array}$ & $\begin{array}{c}\text { рониц емость } \\
\text { обр зцов } \\
\text { после опыт, } \\
10^{-3} \text { мкм }^{2}\end{array}$ & $\begin{array}{c}\text { нижение } \\
\text { прониц емости } \\
\text { обр зцов, \% }\end{array}$ \\
\hline 1 & $20 \% \mathrm{HCl}$ & 0,02 & 5,0 & 216,6 & 213,1 & 1,6 \\
\hline 2 & $20 \% \mathrm{HCl}$ & 0,04 & 5,0 & 142,1 & 185,7 & 3,3 \\
\hline 3 & $20 \% \mathrm{HCl}$ & 0,10 & 5,0 & 122,7 & 120,0 & 2,2 \\
\hline
\end{tabular}

ехнология приготовления водоизоляционной композиции з ключ ется в перемешив нии в цементировочном грег те смеси жидкого стекл $\left(\mathrm{Na}_{2} \mathrm{SiO}_{3}\right)$ и кремнефтористого н трия $\left(\mathrm{Na}_{2} \mathrm{SiF}_{6}\right)$ в течение 15-20 мин. тем в р створ доб вляется г шен я известь $\left(\mathrm{Ca}(\mathrm{OH})_{2}\right)$ и сост в перемешив ется. ост в в течение трех ч сов предст вляет собой подвижную систему, процесс отверждения длится 12 ч и через 24-36 ч он превр щ ется в твердый м тери л.

ост в прод влив ют в и в конце прод вки промыв ют скв жину. кв жину 3 крыв ют и выдержив ют под д влением для прохождения ре кции полимериз ции компонентов р створ [3]. сход водоизоляционной композиции сост вляет от 0,5 до $1,0 \mathrm{~m}^{3}$ н 1 м эффективной толщины пл ст (т бл. 2).

нные технологии могут использов ться при проведении водоизоляционных $\mathrm{p}$ бот н скв жин х, где вскрыты сеном нские и турон-сенонские з лежи.

зменение относительной прониц емости обр зцов керн до и после обр ботки сост вом н основе жидкого стекл

\begin{tabular}{|c|c|c|c|c|c|}
\hline $\begin{array}{c}\text { № } \\
\text { обр зЦ }\end{array}$ & \multicolumn{2}{|c|}{$\begin{array}{c}\text { ост в } \\
\text { р створ , м сс. \% }\end{array}$} & $\begin{array}{c}\text { рониц емость } \\
\text { по воде, } 10^{-3} \text { мкм }{ }^{2} \\
\text { до обр ботки }\end{array}$ & $\begin{array}{c}\text { рониц емость } \\
\text { по воде, } 10^{-3} \text { мкм }^{2} \\
\text { после обр ботки }\end{array}$ & $\begin{array}{l}\text { оэффициент } \\
\text { з купорки, } \\
\text { доли ед. }\end{array}$ \\
\hline 1 & $\begin{array}{l}\mathrm{Na}_{2} \mathrm{SiO}_{3} \\
\mathrm{Na}_{2} \mathrm{SiF}_{6} \\
\mathrm{Ca}(\mathrm{OH})_{2}\end{array}$ & $\begin{array}{c}90,0 \\
9,0 \\
1,0\end{array}$ & 490,3 & 53,9 & 0,89 \\
\hline 2 & $\begin{array}{l}\mathrm{Na}_{2} \mathrm{SiO}_{3} \\
\mathrm{Na}_{2} \mathrm{SiF}_{6} \\
\mathrm{Ca}(\mathrm{OH})_{2}\end{array}$ & $\begin{array}{c}89,0 \\
9,0 \\
2,0\end{array}$ & 513,7 & 46,2 & 0,90 \\
\hline 3 & $\begin{array}{l}\mathrm{Na}_{2} \mathrm{SiO}_{3} \\
\mathrm{Na}_{2} \mathrm{SiF}_{6} \\
\mathrm{Ca}(\mathrm{OH})_{2}\end{array}$ & $\begin{array}{c}88,1 \\
10,6 \\
1,3\end{array}$ & 388,0 & 0 & $\begin{array}{r}\text { олн я } \\
\text { з купорк }\end{array}$ \\
\hline 4 & $\begin{array}{l}\mathrm{Na}_{2} \mathrm{SiO}_{3} \\
\mathrm{Na}_{2} \mathrm{SiF}_{6} \\
\mathrm{Ca}(\mathrm{OH})_{2}\end{array}$ & $\begin{array}{c}86,5 \\
12,0 \\
1,5\end{array}$ & 560,1 & 0 & $\begin{array}{r}\text { олн я } \\
\text { з купорк }\end{array}$ \\
\hline
\end{tabular}


процессе эксплу т ции г зовых и г зоконденс тных скв жин возник ет необходимость в огр ничении поступления подошвенной воды в эксплу т ционные скв жины. сновной причиной поступления воды в скв жину является обр зов ние депрессионной воронки, когд подошвенн я вод прорыв ется в продуктивную ч сть пл ст, вызыв я обводнение скв жины и обр зов ние г зовых гидр тов, что может привести к прекр щению эксплу т ции скв жины. ля огр ничения поступления подошвенной воды в продуктивную ч сть пл ст уст н влив ются технологические экр ны.

пособ огр ничения водоприток в эксплу т ционную скв жину предусм трив ет перфориров ние колонны ниже г зоводяного конт кт ( ) н 5-10 м и проведение гидрор зрыв пл ст ( ), огр ниченного р змер ми депрессионной воронки. осле проведения водон сыщенн я ч сть пл ст эксплу тируется через, отделенн я п кером от поступления воды в скв жину, при добыче г 3 дост точно сниж ть д вление подошвенной воды путем ее отбор из водон сыщенной зоны.

ущность предл г емой технологии состоит в следующем. 3 глушенной скв жине проводят геолого-геофизические исследов ния с целью определения х р ктер н сыщения продуктивного пл ст и определяют положение . скв жине проводится гидропескоструйн я перфор ция н 5-10 м ниже . пуск ют в скв жину с п кером уст н влив емого ниже интерв л перфор ции в г зон сыщенном пл сте, и проводят лок льный огр ниченных р змеров по простир нию и толщине пл ст . ля предотвр щения отриц тельных последствий от при выборе объектов в скв жине приходится их отклонять, если они не имеют глинистого прослоя толщиной до трех метров внутри водон сыщенной ч сти з лежи. бр зов ние трещины в огр ниченном интерв ле возможно лишь в определенном р сстоянии от скв жины, что обеспечив ет высокую вероятность н ч льной ориент ции трещин. ри проектиров нии лок льного р счетным путем определяют темп и объем 3 к чки жидкости $\mathrm{p}$ зрыв, обеспечив ющей $\mathrm{p}$ звитие трещины по длине, $\mathrm{p}$ вной $\mathrm{p}$ диусу депрессионной воронки. нное техническое решение позволяет созд ть в предел $\mathrm{x}$ трещину

высокой проводимости, в результ те повыш ется прониц емость пл ст и увеличив ется приток пл стовой воды в интерв л, котор я отбир ется через, , в интерв ле перфор ции, перекрытом п кером от поступления подошвенной воды, проводится отбор г $з$ из г зон сыщенного пл ст .

редл г емый способ эксплу т ции скв жин ок зыв ется очень эффективным при подтягив нии конус подошвенной воды в г зовых и г зоконденс тных скв жин х, когд поступление воды приводит к обр зов нию и препятствует эксплу т ции скв жин.

ссм трив емые технологии по огр ничению вынос песк и поступления подошвенной воды в г зовые и г зоконденс тные скв жины позволяют увеличить время эксплу т ции скв жин без проведения к пит льного ремонт и объем добычи г 3 и конденс т .

писок литер туры

1. ейхм н . ., озуля . . и др. еория и пр ктик к пит льного ремонт г зовых скв жин в условиях пониженных пл стовых д влений. - $\quad . \quad$.

2. тент оссийск я едер ция 2305765. ник ровский . ., ник ровский . . и др. пособ крепления приз бойной зоны пл ст . публиков но 10. 09. 2007. юл. № 25.

3. тент оссийск я едер ция 2477789. ник ровский . ., ник ровский . . и др. пособ огр ничения водоприток в эксплу т ционную скв жину. публиков но 20. 03. 2013. юл. № 8.

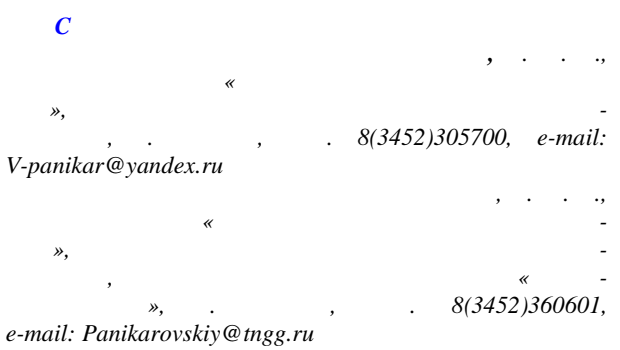

Information about the authors

Panikarovskiy $V . V$., PhD, professor of the chair «Ge ology of oil and gas fields», Tyumen State Oil and Gas University, phone: 8(3452)305700, e-mail: V-panikar@yandex.ru

Panikarovskiy E. V., Candidate of Technical Sciences, associate professor of the chair «Drilling of oil and gas wells», Tyumen State Oil and Gas University, senior scientific worker of the company "TyumenNIIgiprogas. Ltd», phone: 8(3452)360601,e-mail: Panikarovskiy@tngg.ru 